\title{
Exotic and indigenous problem plants species used, by the Bapedi, to treat sexually transmitted infections in Limpopo Province, South Africa
}

\author{
*Semenya SS ${ }^{1}$, Potgieter MJ ${ }^{1}$, Erasmus LJC ${ }^{2}$
}

1. Department of Biodiversity, School of Molecular and Life Sciences, University of Limpopo, Private Bag X1106, Sovenga 0727, South Africa

2. Department of Physiology and Environmental Health, University of Limpopo, Limpopo, South Africa

\begin{abstract}
Background: The ethnic usage of exotics and indigenous problem plants is a highly debated topic, as legislative requirements over-shadow their potential medicinal value, particularly to treat sexually transmitted infections (STIs). Limited information exists regarding their medicinal value among the Bapedi.

Objective: To ascertain the importance of exotics and indigenous problem plants in the treatment of STIs, a major global primary health care challenge.

Methods: A field observation and semi-structured questionnaire focussing on species diversity, types of STIs treated and medicinal preparation as well as application was used to collect data from 34 traditional healers.

Results: Seven exotics and three indigenous problem species were identified. These species were used to treat four STIs; with Catharanthus roseus illustrating its dominance in the treatment of gonorrhoea. Some medicinal species used by Bapedi traditional healers have been validated through scientific research or through their extensive use by various cultures in South Africa and other parts of Africa. To the best of our knowledge Alternanthera pungens, Caesalpinia decapetala, Cinnamomum verum, and Citrullus lanatus are reported for the first time in the treatment of the investigated STIs.

Conclusion: Exotic and indigenous problem species constitute an important component of the STIs treatment protocol. Their utilization by Bapedi cautions against the narrow-minded approach of indiscriminate eradication, as these species can play a significant role in the primary health care needs of socio-economic vulnerable people.
\end{abstract}

Keywords: Bapedi, exotics, indigenous problem plants, sexually transmitted infections.

African Health Sciences 2013; 13(2): 320 - 326 http://dx.doi.org/10.4314/ahs.v13i2.17

\section{Introduction}

Exotic species are widespread in South Africa, both in cultivated and communal areas. At least 161 species have been declared as exotics, and cause serious problems in natural and semi-natural systems ${ }^{1}$, impacting on approximately $80 \%$ of the country ${ }^{2}$, or roughly 20 million hectares.

According to Lewu and Afolayan ${ }^{3}$, the medicinal importance of exotic and problem species should be documented and appraised, or else valuable species may be lost through improper management. Plants can be ecologically ${ }^{4}$, socially, and

*Corresponding author:
Sebua Silas Semenya
Department of Biodiversity, School of Molecular
and Life Sciences
University of Limpopo
Private Bag X1106
Sovenga 0727, South Africa
Tel: +27 152683126
Email: Sebuasemenya@gmail.com

economically significant ${ }^{5}$, irrespective of whether they are native or not.

Some indigenous plant species are declared via Conservation of Agricultural Resource Act no. 43 of $1983^{6}$ as problem or weedy species. This is because they are mostly found growing in agricultural lands, gardens, along road sides and disturbed areas where they do not depend on human intervention for their reproduction or survival ${ }^{7}$. The South African Government has adopted chemical, physical and biological strategies to control some of these species.

Lennox et al. ${ }^{8}$, however, cautioned against the wholesale eradication of exotic and indigenous problems species, as some of them have the potential to advance social upliftment. Semenya et al. ${ }^{9}$ showed that exotics play an important role in the lives of rural communities, with regard to medicine, food security, for ornamental purposes as well as their contribution to primary health care.

In Africa primary health care systems are burdened by the prevalence of sexually transmitted infections (STIs). Exotic as well as indigenous 
problem species are used in the treatment of STIs by natives of South Africa. For example, the Xhosa people of the Eastern Cape Province use Opuntia ficus-indica (L.) Mill., an exotic, to treat dirty blood; an ailment that is believed by traditional healers to be transmitted mainly via sexual intercourse ${ }^{10}$. In the Limpopo Province, Vha-Venda traditional healers use roots of Solanum panduriforme E. Mey., an indigenous problem species, to treat unspecified sexually transmitted infections ${ }^{11}$. Semenya $e t$ al. ${ }^{9}$ found that exotic species, such as Caesalpinia decapetala (Roth) Alston. and Senna didymobotrya (Fresen.) Irwin \& Barneby, play a vital role in the lives of residents of Thulamela municipality, Venda region. These species are used either in combination or alone to treat STIs, clearly illustrating the medicinal value of exotic and problem species in the traditional health care system.
Although it is well-known that exotics and indigenous problem species play an integral role in the lives of rural inhabitants, nothing or very little is known of their value in the traditional health care of the Bapedi. This is one of the larger acknowledged ethnic groups that dominate the Limpopo Province of South Africa, comprising almost $57 \%$ of the population ${ }^{12}$. The current study, therefore aimed at documenting some of the exotic and problem species use by them in the treatment of STIs.

\section{Methods \\ Study area}

The study was conducted in the Limpopo Province, South Africa, and included 17 local municipalities from the Capricorn, Sekhukhune and Waterberg districts as indicated in table 1.

Table 1: Surveyed municipal districts and local municipalities of the Limpopo province

\begin{tabular}{lll}
\hline Capricorn district & Sekhukhune district & Waterberg district \\
\hline Aganang & Elias Motsoaledi & Bela-Bela \\
Blouberg & Fetakgomo & Lephalale \\
Lepelle-Nkumpi & Groblersdal & Modimolle \\
Molemole & Makhuduthamaga & Mogalakwena \\
Polokwane & Marble Hall & Mookgophong \\
& Tubatse & Thabazimbi \\
\hline
\end{tabular}

Ethnobotanical survey and data collection

The survey was conducted, from March 2010 to July 2011, in each of the above municipalities. Data were collected by means of a semi-structured questionnaire, requesting information regarding the use of exotic and problem species in the treatment of STIs. Two traditional healers were randomly selected from each local municipality resulting in 34 being interviewed, at their homes.

\section{Collection of plant materials}

Medicinal plant materials were collected by researchers from both home gardens and wild during organized tours while accompanied by a traditional healer. The species were initially identified by their local names and their proper identification was done using the herbarium of the University of Limpopo (Larry Leach Herbarium). Voucher specimens of each plant were prepared and deposited at the mentioned Herbarium.

African Health Sciences Vol 13 Issue 2 June 2013

\section{Results}

A total of ten species from nine families were identified as being used by Bapedi traditional healers, to treat STIs such as chlamydia (khutlega), gonorrhoea (drop), HIV/AIDS, nta (Bapedi-terminology) and Syphilis (table 2). Six of these species, were exotics and four were declared indigenous problem in South Africa.

Of the 17 municipalities targeted (table 1), traditional healers from 15 indicated that they used exotic and indigenous problem species to treat STIs. Among these municipalities 20 applications were observed, 15 (75\%) favouring the use of exotics, with the remainder preferring indigenous problem species (table 3). In 11 of the municipalities exotics were exclusively used to treat STIs. However, in Makhuduthamaga no exotics were used. In Groblersdal and Lephalale a combination of exotics and indigenous problem species were used.

With the exception of Cinnamomum verum (HIV/AIDS), all other exotics are used in the treatment of gonorrhoea. Regarding indigenous 
problem species Cucumis myriocarpus subsp. leptodermis is the only species that is used to treat more than one STI (gonorrhoea and syphilis). Other indigenous problem species such as Citrullus lanatus (HIV/AIDS),
Solanum panduriforme (gonorrhoea) and Tribulus terrestris (chlamydia) are used to treat a single STI (table 2).

Table 2: Plant species used per district to treat sexually transmitted infections

\begin{tabular}{|c|c|c|c|c|c|}
\hline Family & Species name & Vernacular name & $\begin{array}{l}\text { Capricorn } \\
\text { district }\end{array}$ & $\begin{array}{l}\text { Sekhukhune } \\
\text { district }\end{array}$ & $\begin{array}{l}\text { Waterberg } \\
\text { district }\end{array}$ \\
\hline Amaranthaceae & $\begin{array}{l}\text { Alternanthera pungens } \\
\text { Kunth }\end{array}$ & Motsweetswe & & & $1(1)$ \\
\hline Apocynaceae & $\begin{array}{l}\text { Catharantbus roseus (L.) } \\
\text { G. Don }\end{array}$ & $\begin{array}{l}\text { Lepolomo le le pinki } \\
\text { la drop }\end{array}$ & $1(9)$ & $1(10)$ & $1(9)$ \\
\hline Cactaceae & $\begin{array}{l}\text { Opuntia ficus-indica (L.) } \\
\text { Mill. }\end{array}$ & Motloro & & $1(1)$ & $1(1)$ \\
\hline Caricaceae & Carica papaya $\mathrm{L}$. & Mophopho "wapoo" & & & $1(1)$ \\
\hline Cucurbitaceae & $\begin{array}{l}\text { Cucumis myriocarpus } \\
\text { subsp. leptodermis }\end{array}$ & Magapyana & & $5(1)$ & $1(1)$ \\
\hline Cucurbitaceae & $\begin{array}{l}\text { Citrullus lanatus } \\
\text { (Thunb.) Matsum. \& } \\
\text { Nakai }\end{array}$ & Morotse & & & $2(1)$ \\
\hline Fabaceae & $\begin{array}{l}\text { Caesalpinia decapetala } \\
\text { (Roth) Alston. }\end{array}$ & Mokgabane & $1(1)$ & & \\
\hline Lauraceae & $\begin{array}{l}\text { Cinnamomum verum } \mathrm{J} \text {. } \\
\text { Presl. }\end{array}$ & Unknown & & & $2(1)$ \\
\hline Solanaceae & $\begin{array}{l}\text { Solanum panduriforme E. } \\
\text { Mey. }\end{array}$ & Thola ye serolwane & & $1(2)$ & \\
\hline Zygophyllaceae & Tribulus terrestris L. & Mosehlo & & & $3(1)$ \\
\hline
\end{tabular}

1 (gonorrhoea); 2 (HIV/AIDS); 3 (Chlamydia); 4 (nta); 5 (Syphilis); Bracketed numbers (number of healers who use the species to treat STI).

Table 3: Exotic and indigenous problem plant species used to treat STIs

\begin{tabular}{|c|c|c|c|c|c|}
\hline \multicolumn{2}{|c|}{$\begin{array}{l}\text { Local } \\
\text { municipality }\end{array}$} & \multirow{2}{*}{ 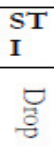 } & \multirow{2}{*}{$\begin{array}{l}\text { Plant } \\
\text { combinations } \\
\text { C. decapetala } \\
\text { (root). }\end{array}$} & \multirow{2}{*}{$\begin{array}{l}\text { Preparation } \\
\text { Boil for } 10 \\
\text { minutes }\end{array}$} & \multirow{2}{*}{$\begin{array}{l}\text { Administration / Dosage } \\
\begin{array}{l}\text { One tin cup ( } 300 \mathrm{ml}) \text { of the extract taken } \\
\text { orally. Thrice daily for a week }\end{array}\end{array}$} \\
\hline \multirow{4}{*}{ 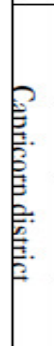 } & Blouberg & & & & \\
\hline & $\begin{array}{l}\text { Lepelle- } \\
\text { Nkumpi }\end{array}$ & ఫ্ট㔾g & C. roseus (root). & $\begin{array}{l}\text { Boil for } 5 \\
\text { minutes }\end{array}$ & $\begin{array}{l}\text { One tin cup of the extract taken orally. Thrice } \\
\text { daily for a week }\end{array}$ \\
\hline & Molemole & $\underset{8}{\nabla}$ & C. roseus (root). & $\begin{array}{l}\text { Boil for } 20 \\
\text { minutes }\end{array}$ & $\begin{array}{l}\text { One tin cup of extract taken orally. Thrice } \\
\text { daily for a week }\end{array}$ \\
\hline & Polokwane & $\underset{0}{g}$ & C. roseus (root). & $\begin{array}{l}\text { Boil for } 5 \\
\text { minutes }\end{array}$ & $\begin{array}{l}\text { One cup of warm extract orally. Thrice daily } \\
\text { for a tweek }\end{array}$ \\
\hline \multirow{7}{*}{ 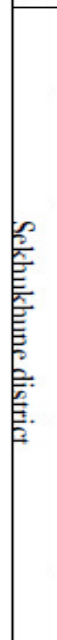 } & $\begin{array}{c}\text { Elias } \\
\text { Motsoaledi }\end{array}$ & ? & C. rosens (root). & $\begin{array}{l}\text { Boil for } 20 \\
\text { minutes }\end{array}$ & $\begin{array}{l}\text { One tin cup of the extract taken orally. Thrice } \\
\text { daily for a week }\end{array}$ \\
\hline & Fetakgomo & & C. roseus (root). & Boil for 20 & en orally ( 1 tin \\
\hline & & है & $\begin{array}{l}\text { O. ficus-indica } \\
\text { (root). }\end{array}$ & munutes & \\
\hline & Groblersdal & $\underset{3}{\square}$ & C. raseus (root). & $\begin{array}{l}\text { Boil for } 20 \\
\text { minutes }\end{array}$ & $\begin{array}{l}\text { One tin cup of extract taken orally. Thrice } \\
\text { daily for a week }\end{array}$ \\
\hline & & 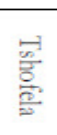 & $\begin{array}{l}\text { C. myriocarpus } \\
\text { subsp. } \\
\text { leptodermis (root } \\
\text { stock). }\end{array}$ & $\begin{array}{l}\text { Boil for } 20 \\
\text { minutes }\end{array}$ & $\begin{array}{l}\text { One tin cup of the extract taken orally. Thrice } \\
\text { daily for a week }\end{array}$ \\
\hline & $\begin{array}{l}\text { Makluudutha } \\
\text { maga }\end{array}$ & $\underset{g}{\ominus}$ & $\begin{array}{l}\text { S. panduriforme } \\
\text { (fruit). }\end{array}$ & $\begin{array}{l}\text { Chopped } \\
\text { and } \\
\text { macerated in } \\
\text { warm water } \\
\text { for } 24 \text { hours. }\end{array}$ & $\begin{array}{l}\text { One cup of decoction administered by healer } \\
\text { twice daily for a week }\end{array}$ \\
\hline & Marble Hall & ఫ্টة & C. rosens (root). & $\begin{array}{l}\text { Boil for } 20 \\
\text { minutes }\end{array}$ & $\begin{array}{l}\text { One tin cup of the extract taken orally. Thrice } \\
\text { daily for a week }\end{array}$ \\
\hline
\end{tabular}




\begin{tabular}{|c|c|c|c|c|}
\hline Bela-Bela & $\sum_{Ð}^{\Xi}$ & $\begin{array}{l}\text { Equal amounts of } \\
B . \text { africana (root), } \\
\text { C. verum (root), } H \text {. } \\
\text { bemerocallidea } \\
\text { (tuber) and } G \text {. } \\
\text { aspera (entire } \\
\text { plant). }\end{array}$ & $\begin{array}{l}\text { Boil for } 20 \\
\text { minutes }\end{array}$ & $\begin{array}{l}\text { One tin cup of extract taken orally. Thrice } \\
\text { daily for a week }\end{array}$ \\
\hline \multirow[t]{2}{*}{ Lephalale } & $\underset{\Xi}{\varnothing}$ & $\begin{array}{l}\text { Combined equal } \\
\text { amounts of } C \text {. } \\
\text { papaya (root) and } \\
\text { C. myrrocarpus (root } \\
\text { stock). }\end{array}$ & $\begin{array}{l}\text { Boil for } 20 \\
\text { minutes }\end{array}$ & $\begin{array}{l}\text { One tin cup of extract taken orally. Thrice } \\
\text { daily for a week }\end{array}$ \\
\hline & 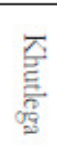 & $\begin{array}{l}\text { Combined equal } \\
\text { amounts of } T \text {. } \\
\text { terrestris (root) and } \\
Z \text {. mucronata (root). }\end{array}$ & $\begin{array}{l}\text { Boil for } 20 \\
\text { minutes }\end{array}$ & $\begin{array}{l}\text { One tin cup of extract taken orally. Thrice } \\
\text { daily for a week }\end{array}$ \\
\hline Modimolle & $\underset{\Xi}{\odot}$ & C. roseus (root). & $\begin{array}{l}\text { Boil for } 20 \\
\text { minutes }\end{array}$ & $\begin{array}{l}\text { One tin cup of extract taken orally. Thrice } \\
\text { daily for a week }\end{array}$ \\
\hline Mogalakwena & $\underset{\Xi}{\varnothing}$ & $\begin{array}{l}\text { O. ficus-indica (root) } \\
\text { and } Z \text {. mucronata } \\
\text { (root). }\end{array}$ & $\begin{array}{l}\text { Boil for } 20 \\
\text { minutes }\end{array}$ & $\begin{array}{l}\text { One tin cup of extract taken orally. Thrice } \\
\text { daily for a week }\end{array}$ \\
\hline Mogalakwena & $\underset{8}{\nabla}$ & C. roseus (root). & $\begin{array}{l}\text { Boil for } 20 \\
\text { minutes }\end{array}$ & $\begin{array}{l}\text { One tin cup of extract taken orally. Thrice } \\
\text { daily for a week }\end{array}$ \\
\hline \multirow[t]{2}{*}{ Thabazimbi } & 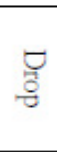 & A. pungens (tuber). & $\begin{array}{l}\text { Macerated } \\
\text { in cow's } \\
\text { milk for } 24 \\
\text { hours }\end{array}$ & $\begin{array}{l}\text { One cup of the decoction taken orally } \\
\text { thrice daily for a week }\end{array}$ \\
\hline & $\sum_{\Xi}$ & $\begin{array}{l}\text { Combined equal } \\
\text { amounts of } C \text {. } \\
\text { lanatus (root), } D \text {. } \\
\text { angustifolia (root) } \\
\text { and } E \text {. crispa (root). }\end{array}$ & $\begin{array}{l}\text { Boil for } 20 \\
\text { minutes }\end{array}$ & $\begin{array}{l}\text { One tin cup of extract taken orally. Thrice } \\
\text { daily for a week }\end{array}$ \\
\hline
\end{tabular}

*Water was used to boil extract

\section{Discussion}

In the Limpopo Province, Bapedi traditional healers use a variety of exotic and indigenous problem species to treat STIs (table 3). This therapeutic application slants overwhelmingly towards the use of exotic species, both by traditional healers as well as its use across municipalities. Furthermore, of all STIs gonorrhoea (drop) were the most treated.

Exotic species are often ignored in ethnobotanical studies and deserve more attention ${ }^{13}$, for they are rich in pharmacologically active substances ${ }^{14}$. In addition, their role in different cultures must be carefully analysed in order to avoid undue conclusions concerning acculturation and erosion of knowledge. This study noted that traditional healers within every district; from all municipalities, excluding those of Aganang and Tubatse, used exotics to treat STIs. These included $A$. pungens, $C$. decapetala, C. papaya, C. roseus, C. verum and O. ficusindica.
Alternanthera pungens tuber is used to treat gonorrhoea. This is a first record of its use as a medicinal species in South Africa. However, it is used medicinally in Africa and other parts of the world. Even though no linkage regarding its use in the treatment of STIs could be located, it is used to treat other ailments. For instance, Tapsoba and Deschamps ${ }^{15}$ noted its use to treat affected gums by the Mossi ethnic group in the Kadiogo Province, Burkina Faso. The Mapuche community in Northwestern Patagonia, Argentina use $A$. pungens to treat hepatic-intestinal ailments ${ }^{16}$. Its medicinal use by diverse cultures across various areas is an indication that it might be safe as a remedy.

Caesalpinia decapetala roots are used to treat gonorrhoea, in the Blouberg municipality (Capricorn district). Similarly Semenya et al. ${ }^{9}$ reported its use by Vha-Venda traditional healers to treat unspecified STIs. However, these two ethnic groups differed in 
their preference with regard to the plant parts used, as the Vha-Venda use extracts prepared from both roots and bark. The exclusive use of this species by healers in the Blouberg municipality might be linked to its abundance in that area, as it is a highly invasive species $^{6}$. This linkage between abundance and usage warrants further investigation.

Carica papaya roots (in conjunction with $C$. myriocarpus subsp. leptodermis rootstock) are used, by Bapedi traditional healers, to treat gonorrhoea. A similar finding, regarding the use of $C$. papaya in the treatment of STIs, was reported for the Venda region ${ }^{11}$. However, lay people in northern Maputaland, KwaZulu-Natal exclusively use either leaves or root of the $C$. papaya, in conjunction with other species to treat STIs ${ }^{17}$. There are distinct ethnic preferences concerning the plant parts used. Bapedi and Vha-Venda prefer to orally prescribe extracts prepared from roots, whilst lay people prefer either leaves or root. Preference for leaves also extends to traditional healers operating in Zambia ${ }^{18}$ and Ghana ${ }^{19}$. It is postulated that the wide usage of $C$. papaya by different cultures, indicate that it might be effective in the treatment of gonorrhoea and other STIs.

Catharanthus roseus was the most frequently reported species and was used exclusively to treat gonorrhoea. Further evidence supporting its medicinal applications for STIs can be found in Fernandes et al. ${ }^{20}$ for the Vha-Venda use of roots to treat urogenital infections, which in itself can be a result of STIs. Although literature supports the use of this species for a multitude of ailments, through various plant parts, none could be found that irrevocably link it to the treatment of gonorrhoea. Under the Bapedi this linkage is so strong that its vernacular name "Lepolomo le le pinki la drop" alludes to its exclusive use as a treatment for gonorrhoea ${ }^{21}$. This strong linkage between roots and gonorrhoea is currently the subject of an on-going investigation. Its purpose is to investigate the antimicrobial potential of $C$. roseus root extracts on Gram-negative bacteria such as, but not limited to, Neisseria gonorrboea. Clinically-significant results could lead to the establishment of novel therapeutic leads.

After an exhaustive search no information regarding the use of $C$. verum in the treatment of HIV/AIDS, was found. However, Van Wyk and Wink $^{22}$ reported its use to treat gastro-intestinal spasms and loss of appetite. Poor appetite is one of the most common problems in people with HIV/AIDS ${ }^{23}$. In Morocco, C. verum bark is use as a stimulant and a remedy for headaches, colds and loss of memory ${ }^{24}$. According to Health $24^{25}$, persistent headaches and depression are common symptoms in the latent stage of HIV/AIDS. Therefore, suggesting that $C$. verum is used in a secondary capacity to treat HIV/AIDS related symptoms, rather than in reducing the viral load or increasing the $\mathrm{CD}^{+}$count.

In this study, O. ficus-indica root extracts were prescribed to patients infected by N. gonorrboea. A decoction prepared from the root fibres of O. ficusindica, with or without the addition of honey, is reported to represent the action of sarsaparilla, which was shown to be useful in the treatment of gonorrhoea ${ }^{26}$. The latter findings validate its use by the Bapedi traditional healers in the treatment of gonorrhoea.

Regarding indigenous problem species, three are currently use by Bapedi traditional healers, to treat STIs. Despite being native to South Africa, C. lanatus, C. myriocarpus subsp. leptodermis and T. terrestris are declared problem or weedy species with strong recommendations and strategies to eradicate or control their growth in cultivated lands and in communal areas ${ }^{6}$. However, these species are medicinally used by Bapedi traditional healers. This study appeals that instead of applying wholesale eradication, they should first be targeted for phytochemical and pharmacological studies with the aim of identifying bio-active compounds with therapeutic potential.

To the best of our knowledge, the use of C. lanatus to treat HIV/AIDS is unrecorded in the literature. This study found that Bapedi healers use it as an immune booster in a multi-extract application. This custom of employing multiple species is in line with Western applications employing multiple therapeutic agents (cocktails) to combat the symptoms and progression of HIV/AIDS. This acknowledges the fact that Bapedi traditional healers understand the complex presentation of this debilitating disease. Currently there is no literature supporting the linkage of $C$. lanatus, as an immune booster, in the treatment of HIV/AIDS.

As far as our literature search goes, there is currently no record in South Africa or elsewhere to support the use $C$. myriocarpus subsp. leptodermis by traditional healers for the treatment of gonorrhoea and syphilis. Phytochemical screening of some wild Cucurbitaceae species from South-East Nigeria, revealed alkaloids, flavonoids, phenols, saponin and tannins in all the plant parts and in all the plant species analysed ${ }^{27}$. These authors concluded that species of African Health Sciences Vol 13 Issue 2 June 2013 
the Cucurbitaceae can be utilized in the treatment of a significant number of diseases including STIs, and also be exploited for use in the pharmaceutical industry.

This study found that a decoction of watermacerated fruits of $S$. panduriforme is used by Bapedi healers as a remedy for gonorrhoea. This is the only account according to our knowledge regarding this procedure, as no literature could be located to support the use of macerated fruits. However, among the Vha-Venda, the roots are used to treat unspecified STIs ${ }^{11}$.

Bapedi traditional healers use T. terrestris to treat chlamydia. This finding is similar to that reported by Mabogo ${ }^{23}$ in the Venda region. However, there is a difference between Vha-Venda and Bapedi with regard to the parts used. Bapedi healers prefer using the whole plant (flowers, fruit, stem, leaf and root), while Vha-Venda healers only use the leaves ${ }^{28}$. Cultural and indigenous preferences between Bapedi and Vha-Venda concerning the use of plant parts might have contributed to the observed variations. In other parts of the world T. terrestris is used to treat other STIs and related symptoms. For example, in Pakistan, leaves are traditionally used to cure gonorrhoea, and the fruit is said to be useful in urinary complaints and painful micturition caused by STI ${ }^{29}$. In India, Muthu et al..$^{30}$ reported the use of roots to prevent white discharge in women and to treat urinary infections. Thus the use of T. terrestris by Bapedi traditional healers, in South Africa, is ethnically validated.

\section{Conclusion}

It is clear from this study that exotic and indigenous problem species constitute an important component of the STIs treatment protocol. This practice is not limited to the Bapedi, but also extends to other southern African ethnic groups. The wide application of this group of species cautions against the narrowminded approach of indiscriminate eradication, as these species can play a significant role in the primary health care needs of socio-economic vulnerable people. It is also worth noting that environmental degradation would, in future, contribute to increased utilisation current and new exotics and indigenous problem species.

\section{Acknowledgements}

The authors are grateful to the traditional healers in the Capricorn, Sekhukhune and Waterberg districts of the Limpopo Province, South Africa for sharing their knowledge on exotic and problem plants species used to treat sexually transmitted infections. The authors also exalt the almighty God for who He is.

\section{References}

1. Macdonald IAW, Reaser JK, Bright C, Neville LE, Howard GW, Murphy SJ, Preston. Invasive alien species in Southern Africa: National reports and directory of resources. Global Invasive Species Programme, Cape Town, South Africa, 2003.

2. Le Maitre DC, Versfeld DB, Champman RA. The impact of alien invading plants on surface water resources in South Africa: A preliminary assessment. Water SA 2000; 26: 397-408.

3. Lewu FB, Afolayan AJ. Ethnomedicine in South Africa: The role of weedy species. African Journal of Biotechnology 2009; 8: 929-934.

4. Crooks JA. Characterizing ecosystem-level consequences of biological invasions: The role of ecosystem engineers. Oiks 2002; 97: 153-166.

5. Ewel JJ, O'Dowd D, Bergelson J, Daehler CC, D'Antonio CM, Gomez LD, Gordon DR, Hobbs RJ, et al. Deliberate introductions of species: Research needs. BioScience 1999; 49: 619_ 630.

6. Conservation of Agricultural Resources Act. (Act no. 43 of 1983). Department of Agriculture, South Africa, Pretoria, 1983.

7. Casas A, Vazquez MD, Viveros JL, Caballero J. Plant management among the Nahua and the Mixtec in the Balsas river basin, Mexico: An ethnobotanical approach to the study of plant domestication. Journal of Human Ecology 1996; 24: 455-478.

8. Lennox S, Mulaudzi R, Erasmus L, Potgieter M. Not all invasive species are equal! Veld and Flora 2012; 98 (2): 70.

9. Semenya SS, Tshisikhawe MP, Potgieter M.J. Invasive alien plant species: A case study of their use in the Thulamela local municipality, Limpopo Province, South Africa. Scientific Research and Essays 2012; 7: 2363-2369.

10. Dold AL, Cocks ML. The trade in medicinal plants in the Eastern Cape Province, South Africa. South African Journal of Science 2002; 98: 589-597.

11. Arnold HJ, Gulumian M. Pharmacopoeia of traditional medicine in Venda. Journal of Ethnopharmacology 1984; 12: 35-74. 
12. Lodge T. Provincial Government and State Authority in South Africa. Journal of Southern African Studies 2005; 31, 748-749.

13. Bennett BC, Prance GT. Introduced plants in the indigenous pharmacopoeia of Northern South America. Economic Botany 2007; 54: 90102.

14. Voeks RA. Disturbance pharmacopoeias: Medicine and myth from the humid tropics. Annals of the Association of American Geographers 2004; 94: 868-888.

15. Tapsoba H, Deschamps JP. Use of medicinal plants for the treatment of oral diseases in Burkina Faso. Journal Ethnopharmacology 2006; 104: 68-78.

16. Estomba D, Ladio A, Lozada M. Medicinal wild plant knowledge and gathering patterns in a Mapuche community from North-western Patagonia. Journal of Ethnopharmacology 2006; 103:109-119.

17. De Wet H, Nzama VN, Van Vuuren SF. Medicinal plants used for the treatment of sexually transmitted infections by lay people in northern Maputaland, KwaZulu-Natal Province, South Africa. South African Journal of Botany 2012; 78: 12-20.

18. Ndubani P, Hojer B. Traditional healers and the treatment of sexually transmitted illnesses in rural Zambia. Journal of Ethnopharmacology 1999; 67: $15-25$.

19. Abbiw DK. Useful plants of Ghana. West African uses of wild and cultivated plants. Intermediate Technology Publications, London and Royal Botanic Gardens, Kew, 1990.

20. Fernandes 1, Van Rensburg CEJ, Hoosen AA, Steenkamp V. In vitro activity of medicinal plants of the Venda region, South Africa, against Trichomonas vaginalis. South African Journal of Epidemiology Infections 2008; 23: 26-28.

21. Semenya SS, Potgieter MJ. Catharanthus roseus (L.) G. Don.: Extraordinary Bapedi medicinal herb for gonorrhoea. Journal of Medicinal Plants Research 2013; 7: $1434-1438$.

22. Van Wyk B-E, Wink M. Medicinal Plants of the World. $1^{\text {st }}$ edition. In: Ferreira, R. (ed.). Briza Publications. Pretoria, South Africa, 2004.

23. Department of Health. South African Guidelines on nutrition for people living with T.B., HIV/ AIDS and other chronic debilitating conditions. Government Printers, Pretoria, 2001.

24. Bellakhadar J, Claisse R, Fleurentin J, Younos C. Repertory of standard herbal drugs in the Moroccan pharmacopoea. Journal of Ethnopharmacology 1991; 35: 123-143.

25. Health 24. Symptoms and phases of HIV infection and Aids. Http://www. health24.com/ medical/Condition_centres/777-792-8141756,22216.asp. Accessed: 07 March 2012, 2012.

26. Shedbalkar UU, Adki VS, Jadhav JP, Bapat VA. Opuntia and other cacti: Applications and Biotechnological insights. Tropical Plant Biology 2010; 3: 136-150.

27. Edeoga HO, Osuagwu GGE, Omosun G, Mbaebie BO, Osuagwu AN. Pharmaceutical and therapeutic potential of some wild Cucurbitaceae species from South-East Nigeria. Recent Research in Science and Technology 2010; 2: 63-68.

28. Mabogo DEN. The ethnobotany of the VhaVenda. M.Sc. Dissertation. University of Pretoria, Pretoria, 1990.

29. Akram M, Asif HM, Akhtar N, Shah PA, Uzair M, Shaheen G, Shamim T, Ali Shah SM, Ahmad K. Tribulus terrestris L.: A review article. Journal of Medicinal Plants Research 2011; 5: 3601-3605.

30. Muthu C, Ayyanar M, Raja N, Ignacimuthu S. Medicinal plants used by traditional healers in Kancheepuram District of Tamil Nadu, India. Journal of Ethnobiology and Ethnomedicine 2006; 2: $1-10$. 